\title{
NIH under fire over gene-therapy trials...
}

Washington

A leading US congressional Democrat last week attacked the National Institutes of Health (NIH) for its failure to properly oversee patient safety in gene-therapy clinical trials, and suggested that responsibility for this be transferred to the Office of the Secretary of Health and Human Services (HHS).

Congressman Henry Waxman (Democrat, Los Angeles) wrote to Ruth Kirschstein, the acting director of the NIH, on 10 January, saying that he was "dismayed" at the frequency with which NIH-funded gene therapists failed to report serious adverse events to the agency.

Waxman referred to figures in a letter he received last month from Harold Varmus, then the outgoing NIH director. Varmus reported that 652 of 691 serious adverse events in human trials using adenoviral vectors were not immediately reported to the $\mathrm{NIH}$, as required by its regulations - a 94 per cent non-compliance rate.

The figures were generated by an NIH request to scientists last October for reports on serious adverse events, after an 18-yearold research subject died in a trial using adenovirus at the University of Pennsylvania. Investigators responded with reports of 691 events, only 39 of which were reported at the time they occurred.

Waxman, who will chair the House Government Reform and Oversight Committee if the Democrats re-take the House of Representatives this November, asked Kirschstein to comment by 21 January on this failure.

Anne Thomas, a spokeswoman for Kirschstein, claims that the NIH has "served the public interest very well" by helping to ensure the safety and efficacy of gene therapy. But, she added, "there is always room for improvement".

Waxman implied that the NIH bore some responsibility for investigators' underreporting by having failed to give clear instructions to its Recombinant DNA Advisory Committee (RAC). The committee publicly oversees gene-therapy protocols and is the NIH body that receives reports of adverse events from scientists. Reports must also go to the US Food and Drug Administration (FDA).

"I am particularly interested in whether you agree that the NIH has contributed to... non-compliance by raising doubts concerning the RAC's existence [and] by curtailing the RAC's authority over gene-therapy protocols," he wrote.

Waxman opposed a 1996 proposal by Harold Varmus, then the NIH director, to disband the RAC (see Nature 382, 197; 1996). The proposal was later modified to

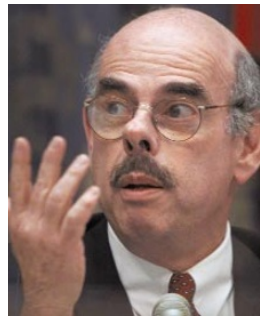

preserve the committee, but without its former authority to approve or disapprove particular experiments. That role now rests solely with the FDA, which by law must keep its deliberaWaxman: "dismayed" tions private. by reporting failures. Some people in industry say that investigator non-compliance is beside the point, because the NIH does not have the legal authority to require reports of adverse events - this authority rests with the FDA - or the human resources to assess them.

"The question of compliance is misconstrued," says Barrie Carter, the director of research and development at Targeted Genetics, a Seattle gene-therapy company. "Even if the data are sent to [the NIH] it's not clear they can compile them." He doesn't think that moving the NIH's gene-therapy oversight to the HHS secretary's office is useful.

Waxman's letter also laments NIH's failure to establish a public database of human gene-therapy protocols, including reports of adverse events. The agency announced plans for the database in 1996. He asks the NIH to have the database operational by the end of this year.

The NIH "must remedy the apparent problems in its oversight of this important field of research", wrote Waxman. He then asked Kirschstein to comment "on whether the public interest would be best served by transferring the RAC and [its administrative office] from NIH to the office of the HHS Secretary".

According to Michael Werner, the Biotechnology Industry Organization's lobbyist on gene-therapy issues, the role of the RAC "is not to be a regulatory agency, it's to do public discussion of social and ethical points". He adds that "whether or not that takes place in the office of the [HHS] secretary or at NIH may be beside the point".

Moving the RAC to the higher-profile HSS secretary's office would mirror a similar move already underway - the NIH office that oversees research involving human subjects was recently elevated to the office of the HHS secretary.

Meredith Wadman

\section{... as panel seeks help for trial host nations}

\section{Washington}

The US National Bioethics Advisory Commission may recommend that protocols for US clinical trials carried out in developing countries should be adapted to the local health infrastructure so the host country can gain maximum benefit from the trials.

The commission is expected to issue guidelines this summer on US

researchers' obligations to host developing countries and to their research subjects. A panel of the commission met last week to discuss the extent to which the United States should assist host countries. Proposed involvement ranged from tailoring trials to a developing nation's biomedical capacity to building up the country's infrastructure to match the needs of the research.

"It does no good to develop therapies that the host country cannot continue to use," Robert Levine, a professor at Yale University
School of Medicine, told the panel. For example, a trial in sub-Saharan Africa on how to minimize the spread of HIV from pregnant mothers to their fetuses would seem a worthy effort in the short term, but would not necessarily be of long-term help to the community.

If the community wished to continue the research after the US clinicians had left, it would need prenatal facilities to allow doctors to identify HIV-positive mothers and the equipment and trained personnel necessary to administer the anti-AIDS drug AZT intravenously. It would also need ample supplies of baby formula and clean water to provide an alternative to breastfeeding, as infants would otherwise face an even greater health risk from diarrhoea.

To justify carrying out clinical research in developing countries, US research goals should match the health needs of the host country and should provide the country with the "highest attainable and sustainable" benefits possible after the end of the trial, Levine suggested. For example, a trial of an AIDS vaccine in a developing nation should include provision for further distribution of the vaccine should the trial prove successful.

Ruth Faden, director of the Bioethics Institute at Johns Hopkins University, told the panel that scientists change the community where the studies take place merely by setting up clinical trials, as they introduce - sometimes temporarily - higher levels of health care. As a result, they have an obligation to help that community after the trial ends. "You can't leave the place the way you found it," said Faden, adding that the US government should provide aid to build up infrastructure in developing nations where US-sponsored research takes place.

Paul Smaglik 